\title{
THE INTERACTIVE COMMUNICATION IN WEBCASTING ENVIRONMENT
}

\section{Milan NOVÁK}

\begin{abstract}
The paper presents an analysis of the possibility of interactive communication in webcastingh systems that cerate effective deployment and use. Selecting the appropriate tools for interactive communication can reach more students and increase their motivation in the learning process across different disciplines.
\end{abstract}

Key words: webcasting, education, audio, video, interactivity, communication, education system

\section{MOŽNOSTI INTERAKTIVNÍ KOMUNIKACE VE WEBCASTIGOVÉM PROSTŘEDÍ}

Resumé: Článek předkládá analýzu možností interaktivní komunikace ve webcastingových systémech, která tvoří základ jejich efektivního nasazení a využívání. Zvolením vhodných nástrojů pro interaktivní komunikaci, lze př́ikladněji oslovit studenty a zvýšit jejich motivaci v učícím se procesu např́č různými obory.

Klíčová slova: webcasting, vzdělávání, audio, video, interaktivita, komunikace, vzdělávací systém

\section{1 Úvod}

$\mathrm{V}$ prostředí výukových, resp. webcastingových systémů lze realizovat dva druhy interaktivity. První typ je založený na sociální podstatě interakce. Hovoří se o mezilidské interakci prostrednictvím technologií. Označuje se také jako počítačem zprostředkovaná komunikace. Př́kladem tohoto typu jsou chatovací nebo videokonferenční místnosti, diskusní fóra nebo sdílené aplikace. Tato forma interakce je realizována hlavními komunikačními nástroji, které jsou součástí webcastingových systémů. Druhý typ interakce je založený na technické podstatě interakce, která je představována komunikací člověka s technickým prostředkem typu počítač. Př́kladem je vzdělávací software, virtuální mikrosvěty, simulace atd. Tato forma interakce nelze prímo realizovat webcastingovým systémem, ale vyžaduje zvláštní účelově vyvíjené úsilí.

\section{Fiktivní zpětná vazba}

Přestože webcastingové systémy poskytují různorodé možnosti $\mathrm{v}$ kombinaci výukových objektů a tím zvyšují efektivitu výukového materiálu, důležitou roli hraje interaktivita komunikačních nástrojů. Tento element lze ve webcastingových výukových dokumentech přirovnat $\mathrm{k}$ realizaci interaktivní zpětné vazby. $\mathrm{Z}$ technologické podstaty webcastingových systémů vyplývá, že lze realizovat jak vnějši zpětnou vazbu, tak i vnitřní zpětnou vazbu.
Vnější zpětná vazba je realizovaná prostřednictvím interaktivních nástrojů webcastingového systému, které umožňují překonání lidských limitů v rychlosti předávání a zpracování velkého množství zpětnovazebních informací současně se zajištěním odpovídající kvality a frekvence.

Vnitřní zpětná vazba je základním prostředkem autokontroly a autoregulace při učení. Jejím prostrednictvím dostává student informace o průběhu své učební činnosti a jejích výsledcích, které mají významný vliv na kvalitu procesu osvojování poznatků a činností i na vytvoření motivačních stimulů a hodnotících vztahů.

$\mathrm{Na}$ rozdíl, např́klad od výukové televize, kde realizace zpětné vazby byla omezena na možnost komunikace ve směru od studenta $\mathrm{k}$ učiteli, lze ve webcastingovém systému tuto vazbu modifikovat $\mathrm{v}$ závislosti na typu komunikačního nástroje. Realizace zpětné vazby ve webcastingovém systému se odvíjí od formy výuky, tzn. zda se jedná o synchronní nebo asynchronní výukovou událost. Forma výuky také ovlivňuje možnosti vyhodnocení reakcí studentů.

Pro asynchronní výukovou událost realizovanou webcastingovým systémem, lze pro specifikaci zpětné vazby vyjít $\mathrm{z}$ tzv. varianty fiktivní zpětné vazby. Prostředí webcastingového systému nabízí dvě varianty k uskutečnění fiktivní zpětné vazby. 
První variantou (Obr. 1) je, že výsledný webcastingový materiál bude obsahovat všechny možnosti audiovizuálního záznamu, které mohou nastat $\mathrm{v}$ závislosti na interaktivní volbě studenta. Může se uskutečňovat prostřednictvím volby $\mathrm{z}$ nabízených variant odpovědí, které jsou realizované hypertextovými odkazy v podobě textových nebo obrazových výukových objektů $\mathrm{v}$ kombinaci $\mathrm{s}$ dalšími médii, dále prostřednictvím interaktivních formulářových prvků, jako součásti html stránky. Těmito prvky jsou zejména zaškrtávací pole $\mathrm{s}$ jednou správnou odpovědí, zaškrtávací pole $\mathrm{s}$ více správnými odpověd'mi, výběrové pole s množinou odpovědí, textové pole pro jednoznačnou slovní odpověd’ apod.

Jednotlivé formulářové prvky lze sdružovat do skupin a sledovat celkové skóre odpovědí uživatele. Na základě výsledku je automaticky zobrazen adekvátní audiovizuální záznam. Při asynchronní výukové události jde o typ webcastingového materiálu na vyžádání.

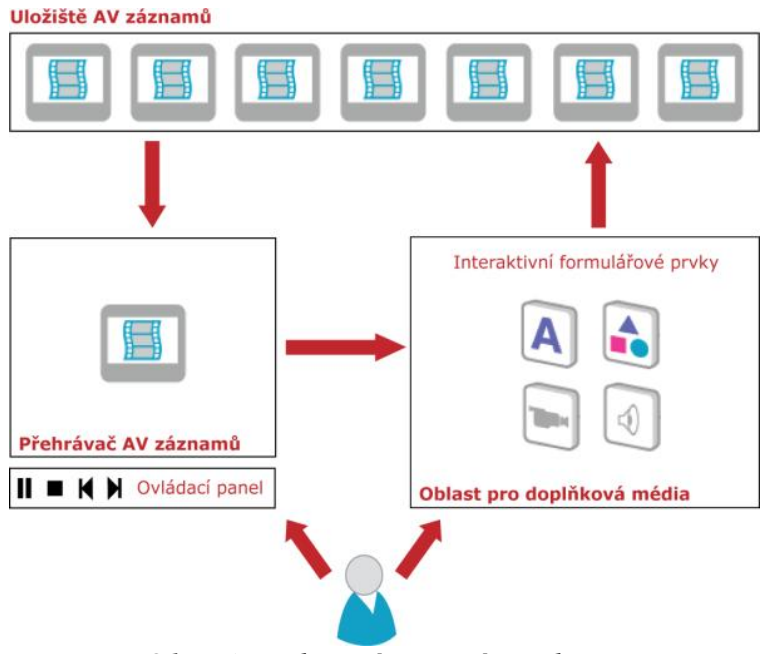

(Obr. 1: Fiktivní zpětná vazba I.)

Lze také využít i aplikace $\mathrm{s}$ interaktivní volbou pro realizaci zpětné vazby, které jsou vytvořeny $\mathrm{v}$ některém $\mathrm{z}$ produktů pro tvorbu výukových a multimediálních programů. Jsou to převážně aplikace $\mathrm{z}$ rodiny produktů společnosti ADOBE. Především se jedná o produkty ADOBE FLASH a AUTHORWARE. Tyto aplikace umožňují širší výběr interaktivních prvků. Jedná se především o všechny formulářové prvky, které jsou doplněny o další možnosti, jako například přiřazování objektů dle správného rozmístění nebo přímá volba správného objektu.
Interaktivní volby zpětné vazby se automaticky zobrazují v konkrétním časovém bodu $\mathrm{v}$ synchronizační smyčce audiovizuálního záznamu. Audiovizuální záznam se zastaví a uživatel se může kdykoliv vrátit zpět. Dále lze ovládat audiovizuální záznam prostřednictvím ovládacího panelu prrehrávače a reagovat na podněty, které jsou dány požadavkem na provedené akce v oblasti doplňkových médií, tj. provést interaktivní volbu. $\mathrm{V}$ závislosti na výsledku provedené volby se $\mathrm{z}$ úložiště audiovizuálních záznamů do přehrávače přiřadí nový, audiovizuální záznam, který se začne opět přehrávat.

Tato varianta klade poměrně velké nároky na tvorbu audiovizuálních záznamů, kterých může být $\mathrm{v}$ závislosti na míře frekvence zobrazování interaktivních prvků velké množství.

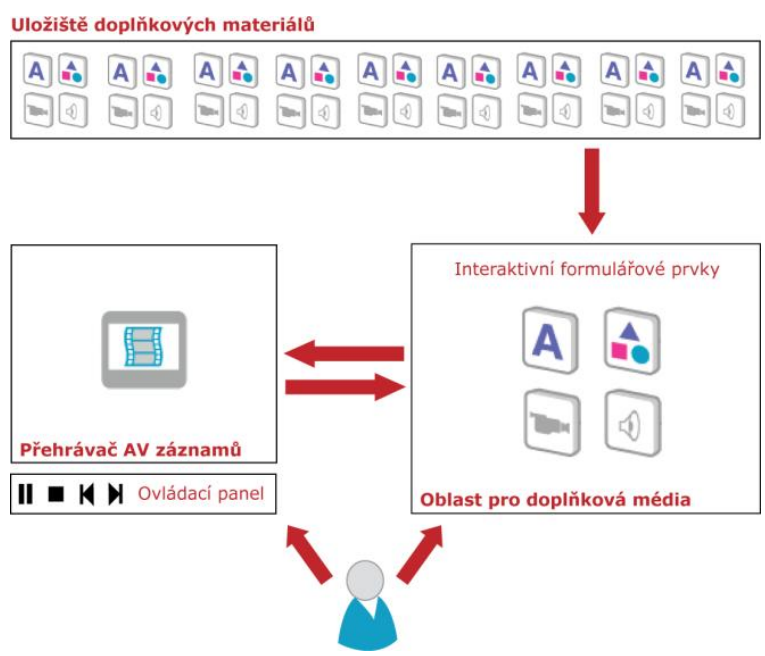

(Obr. 2: Fiktivní zpětná vazba II.)

Druhou variantou fiktivní zpětné vazby je zjednodušení předchozího řešení, které spočívá ve vytvoření nikoliv všech možných variant audiovizuálního záznamu, ale $\mathrm{v}$ interaktivní odezvě v oblasti doplňkových materiálů (Obr. 2). To znamená, že v závislosti na výsledku řešení požadavků, realizovaných interaktivními prvky může dojít $\mathrm{k}$ těmto alternativám:

- Pokud budou výsledky zpětné vazby adekvátní požadavkům, tj. prahovým hodnotám pro pokračování $\mathrm{v}$ průchodu webcastingovým výukovým materiálem, zobrazí se $\mathrm{v}$ oblasti doplňkových médií výukové objekty odpovídající časovému bodu synchronizační smyčky a audiovizuální záznam bude pokračovat v přehrávání. 
- Pokud výsledky nebudou odpovídat prahovým hodnotám pro pokračování $\mathrm{v}$ průchodu webcastingovým materiálem dojde bud' $\mathrm{k}$ zobrazení navrhovaných možností pro další činnost, nebo $\mathrm{k}$ automatickému nastavení časového bodu synchronizační smyčky, který odpovídá dosaženému výsledku uživatelem. Dojde k opakovanému přehrávání audiovizuálního záznamu spolu s doplňkovými materiály od časového bodu až po opětovné dosažení části pro realizaci zpětné vazby.

$\mathrm{V}$ této variantě nedochází $\mathrm{k}$ podsouvání alternativ audiovizuálních záznamů na základě výsledků zpětné vazby, ale $\mathrm{k}$ zobrazení výukových objektů $\mathrm{v}$ závislosti na nastavení časového bodu.

Fiktivní zpětná vazba je určena pro asynchronní výukové materiály, protože se na její realizaci aktivně nepodílí učitel. Přestože se ve výše uvedeném modelu nevyskytují žádné základní asynchronní komunikační prostředky, lze je využít zejména při samostudiu či distančním studiu. Student potom využívá interaktivních prvků zpětné vazby spíše k sebekontrole a asynchronních komunikačních nástrojů $\mathrm{k}$ plnění úkolů, které mohou být součástí výukového materiálu. Prostřednictvím komunikačních nástrojů student komunikuje jednak s uživateli, např́klad $\mathrm{v}$ diskusním fóru nebo skupině, a dále $\mathrm{s}$ učitelem, kterému prostřednictvím elektronické pošty zasílá řešení, na jehož základě získává zpětnou vazbu hodnocení.

\section{Faktická zpětná vazba}

Zpětná vazba pro synchronní výukovou událost realizovanou prostřednictvím webcastingových systémů by mohla vycházet $\mathrm{z}$ tzv. faktické zpětné vazby. $\mathrm{V}$ jejím původním pojetí, tj. v oblasti výukové televize se jednalo o participaci tzv. studiového učitele, který na základě sumarizovaných výsledků vyhodnocoval výkon studentů a rozhodoval o dalším výběru možné varianty.

Ve webcastingovém systému není nutné se této varianty zpětné vazby vzdávat, nicméně technologické možnosti smazávají jasnou linii mezi fiktivní a faktickou zpětnou vazbou $\mathrm{v}$ původním pojetí. Základní rozdíl je $\mathrm{v}$ tom, že se zpětná vazba neaplikuje $\mathrm{v}$ závislosti na výsledcích celé skupiny studentů, ale na individuálním výkonu každého jedince. Webcastingový systém umožňuje podsouvat adekvátní varianty audiovizuálního záznamu tak jak je uvedeno ve fiktivní zpětné vazbě, ale také jak bylo prováděno prostřednictvím studiového učitele - konzervy.

$\mathrm{Z}$ těchto důvodů je vhodnější $\mathrm{v}$ synchronní metodě webcastingového vzdělávání spíše hovořit o zpětné vazbě prímé. Tato př́má vazba se realizuje prostřednictvím synchronních komunikačních nástrojů. $\mathrm{V}$ nejjednodušší podobě, při synchronní výukové události, která je studentům poskytována prostřednictvím webcastingového přenosu, se realizuje zpětná vazba ve směru do studenta $\mathrm{k}$ učiteli. $\mathrm{K}$ této zpětné vazbě se využívá synchronního komunikačního nástroje, kterým je chat. Studenti předávají své dotazy učiteli, který je vidí $\mathrm{v}$ komunikační oblasti webcastingového systému a zpětná vazba probíhá formou př́mých slovních odpovědí v podobě audiovizuálního sdělení. Dochází tak k př́ímé komunikaci. Stejně tak může docházet ke studentské interakci v závislosti na dotazu, který položí učitel formou audiovizuálního sdělení a studenti reagují bud' př́mými odpověd’mi, nebo prostřednictvím interaktivní volby $\mathrm{v}$ oblasti doplňkových materiálů.

\section{Druhy interaktivity}

Ve webcastingovém systému interaktivní komunikace probíhá mezi učitelem a studenty, kteří mohou být jednak $\mathrm{v}$ lokalitě konání výukové události, nebo se jí účastní vzdáleně. Studenti v lokalitě konání budou nazýváni lokálními účastníky výukové události. Bude se jednat o studenty, kteří se účastní hromadné výuky prostřednictvím webcastingového vysílání, například v přednáškové místnosti, kde výuková událost bude prezentována promítanou formou, i když budou mimo prímou lokalitu průběhu výukové události. Vzdálení účastníci výukové události představují individuální sledování webcastingového přenosu prostřednictvím výukového prostředku počítače. Vyskytují se tak různé druhy interaktivity.

- Interakce mezi učitelem a vzdálenými účastniky výukové události. Charakteristickým rysem systému je mechanismus pro vzdálené účastníky s možností klást otázky. Realizace může probíhat prostřednictvím moderátora nebo př́mou vazbou na učitele. Problematikou je zvolení komunikačního kanálu tak, aby u vyučujícího nedocházelo ke ztrátě koncentrace. 
- Interakce mezi vzdálenými účastníky výukové události. Komunikace probíhá přes integrovaný komunikační podsystém. Technologické možnosti webcastingových systémů umožňují komunikaci typu 1:1. Tato komunikace vzdálených účastníků na rozdíl od účastníků lokálních nepůsobí rušivými vlivy na výukovou událost bez rozptylování učitele. Otázkou zůstává, zda možnost komunikace mezi jednotlivými vzdálenými účastníky nevede spíše k jejich nepozornosti.

- Interakce mezi vyučujicím a lokálními účastniky výukové události. Probíhá prostřednictvím mluvčího nebo prrímou komunikací účastníků. Komunikačním kanálem $\mathrm{v}$ tomto př́ípadě může být jednak textová forma, kdy mluvčí zprostředkovaně s využitím chatu sděluje informace nebo audiovizuální forma, což samozřejmě vyžaduje vyšší požadavky na technický výukový systém a jedná se již o videokonferenční systém.

- Interakce mezi lokálními účastníky výukové události. Komunikace probíhá přes mluvčího dané skupiny lokálních účastníků, s využitím komunikačních nástrojů $\mathrm{v}$ předchozím typu interakce. Je otázkou, jak se dá rozvinout př́má diskuze na dané téma s uvedenými nástroji.

- Interakce mezi lokálními a vzdálenými účastniky výukové události. Komunikace ve směru od vzdálených účastníků k lokálním, může probíhat formou chatu, kde zprávy se zobrazují formou projekce jako součást audiovizuálního sdělení. Komunikace ve směru od lokálních účastníků ke vzdáleným, probíhá zprostředkovaně přes moderátora výukové události stejným komunikačním kanálem.

$\mathrm{Na}$ téma interaktivní komunikace se vyskytuje mnoho otevřených otázek. Jednou $\mathrm{z}$ nich je rozsah, ke kterému jsou jednotlivé druhy interakce užitečné a použitelné $(1, \mathrm{~s} .5)$.

\section{Míra odezvy}

Forma př́mé zpětné vazby a potřeba efektivní interakce vede ke zvážení časových aspektů komunikace mezi jednotlivými účastníky výukové události, zejména mezi vyučujícím a studentem. Vlivem různorodého technického řešení nemusí být odezva zcela okamžitá, nicméně je zde jakostní rozdíl mezi odezvou poskytnutou $\mathrm{v} 10$ sekundách, 10 minutách nebo 10 hodinách. Účelem je poskytnutí kvalitní výuky, kde je kladen důraz na důležitost podpory okamžité odezvy asociované s výukovým prostředím.

$\mathrm{V}$ závislosti na různých typech dostupných systémů pro distribuované vzdělávání se hovoří o čtyřech možnostech odezvových časů:

- Reálný čas: odezva v konverzačním módu.

- Rychlá odezva: reakce v čase kratším než jedna minuta, jedná se typicky o zvednutí ruky a čekání, kdy bude student vyvolán.

- Prüměrná odezva: reakce během několika minut, ke zpoždění dochází z důvodu řazení požadavků.

- Pomalá odezva: odpověd' musí čekat na asynchronní participaci, typickým př́kladem je elektronická pošta nebo diskusní fórum.

Jednotlivé odezvy vázané na dostupnost médií ve webcastingových systémech ukazují, že odezva $v$ reálném čase je nejpravděpodobnější při nejmenším zatížení šiřky přenosového pásma, tj. za využití samostatné audiosložky s doprovodnými výukovými objekty (Obr. 3.). Webcastingový přenos s využitím obou složek audio a video inklinuje $\mathrm{k}$ průměrné odezvě. Zatížení komunikačního kanálu streamováním jednotlivých médií, způsobuje opožděné dodání informací jednak ke studentovi a dále od studenta k vyučujícímu (2, s. 101-104).

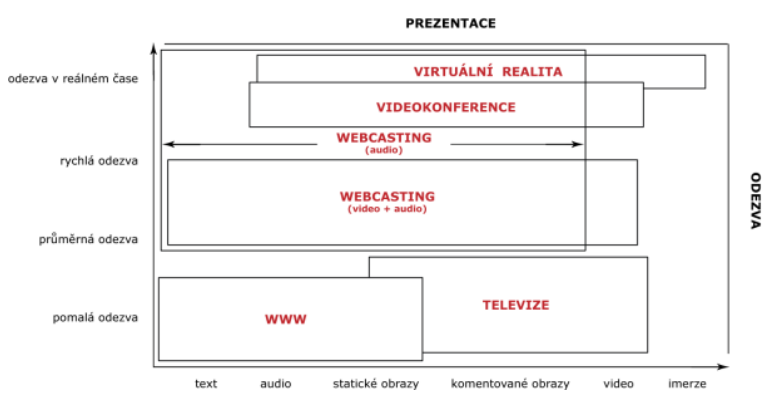

(Obr. 3: Zatížení prenosového pásma)

\section{Závěr}

Přestože současný technologický rozvoj poskytuje celou raadu nových interaktivních nástrojů, některé problémy přetrvávají. Jedná se zejména o objektivní realizaci prímé zpětné vazby. Ani nástup mobilních zařízení v podobě chytrých telefonů nebo tabletů tuto problematiku $\mathrm{v}$ plné míře neřeší. Poskytují další př́stupový kanál $\mathrm{k}$ webcastingovým materiálům, rozšiřují možnosti v podobě okamžitého př́istupu $\mathrm{k}$ těmto 
materiálům, ale prvky zpětné vazby zůstávají. V jistém ohledu spíše kladou více nároků na přizpůsobení webcastingových systémů pro tato mobilní zařízení a to zejména $\mathrm{v}$ poskytování větší variability formátů videa a optimalizaci prezentační části.

\section{Literatura}

[1] BAECKER, R., MOORE, G., ZJINDEMANS, A. Webcasting Made Interactive. In Reinventing the Lecture. University of Toronto : Knowledge Media Design Institute, 2003.

[2] PULLEN, J. M. The Internet-Based Lecture : Converging Teaching and Technology. ACM Special Interest Group on Computer Science Education. 1.1.2002, vol. 3, no. 32.

[3] Using multimedia case studies to advance pre-service teacher knowing. In: International Education Journal. South Australia: Shannon Research Press, 2006, s. 9. ISSN 1443-1475.

[4] SMITH, Michael J a Gavriel SALVENDY. Human interface and the management of information: Symposium on Human Interface 2007, held as part of HCI International 2007, Beijing, China, July 22-27, 2007 : proceedings.
New York: Springer, c2007, 2 v. ISBN 97835407335392.

[5] Giannakos, M. N. and Vlamos, P. (2013), Using webcasts in education: Evaluation of its effectiveness. British Journal of Educational Technology, 44: 432-441. doi: 10.1111/j.14678535.2012.01309.x.

[6] BAECKER, Ronald, Jeremy BIRNHOLTZ, Rhys CAUSEY, Simone LAUGHTON, Kelly RANKIN, Clarissa MAK, Alison WEIR a Peter WOLF. Webcasting Made Interactive: Integrating Real-Time Videoconferencing in Distributed Learning Spaces. Part of HCI International 2007, Beijing, China: Symposium on Human Interface 2007, 2007. ISBN 978-3540-73354-6. DOI: 10.1007/978-3-540-733546_30.

PhDr. Milan Novák, Ph.D.

Ústav aplikované informatiky

Př́rodovědecká fakulta Jihočeské univerzity

Branišovská 31,

37005 České Budějovice, ČR

Tel: +420 605182228

E-mail: novis@prf.jcu.cz

Www pracoviště: http://uai.prf.jcu.cz/ 